\title{
Folding of ortho-Phenylenes
}

\section{Supporting Information}

\section{Scott Hartley*}

Department of Chemistry \& Biochemistry, Miami University, Oxford, OH 45056, USA *scott.hartley@miamioh.edu

\section{Computational Chemistry Data}

Conformational Analysis of o $P^{5}(H)_{5}$

The data in Figure 4 were generated using Gaussian $09,{ }^{1}$ using the B97-D/TZV(2d,2p) method. The geometries were optimized at each point subject to the constraints on $\varphi_{\text {fix }}$ and $\varphi_{\mathrm{var}}$. The scan was performed in both directions to ensure that the lowest-energy geometries were obtained.

Table S1. Computational data for Figure 4.

\begin{tabular}{rrr}
\hline \multirow{2}{*}{$\varphi_{\text {var }}$} & \multicolumn{2}{c}{$E(\mathrm{kcal} / \mathrm{mol})$} \\
\cline { 2 - 3 } & $\varphi_{\text {fix }}=-55^{\circ}$ & $\varphi_{\text {fix }}=+130^{\circ}$ \\
\hline$-175^{\circ}$ & 13.82 & 16.21 \\
$-160^{\circ}$ & 17.53 & 17.40 \\
$-145^{\circ}$ & 15.75 & 13.79 \\
$-130^{\circ}$ & 14.18 & 11.22 \\
$-115^{\circ}$ & 10.00 & 10.15 \\
$-100^{\circ}$ & 7.65 & 6.40 \\
$-85^{\circ}$ & 4.45 & 3.98 \\
$-70^{\circ}$ & 1.21 & 2.72 \\
$-55^{\circ}$ & 0.00 & 3.24 \\
$-40^{\circ}$ & 1.26 & 6.00 \\
$-25^{\circ}$ & 4.92 & 10.36 \\
$-10^{\circ}$ & 10.84 & 15.90 \\
$5^{\circ}$ & 18.56 & 22.80 \\
$20^{\circ}$ & 26.22 & 27.21 \\
$35^{\circ}$ & 30.95 & 20.63 \\
$50^{\circ}$ & 28.46 & 15.81 \\
$65^{\circ}$ & 22.87 & 11.51 \\
$80^{\circ}$ & 16.72 & 8.37 \\
$95^{\circ}$ & 11.43 & 6.93 \\
$110^{\circ}$ & 7.08 & 5.56 \\
$125^{\circ}$ & 3.86 & 4.70 \\
$140^{\circ}$ & 2.86 & 5.16 \\
$155^{\circ}$ & 4.44 & 7.26 \\
$170^{\circ}$ & 8.25 & 11.15 \\
\hline & &
\end{tabular}

Folding of Hexa(Pyrazine-2,3-diyl)

To compare the inherent folding preferences of oligo(o-phenylene)s and oligo(pyrazine-2,3-diyl)s, the geometry of hexa(pyrazine-2,3-diyl) was optimized in both the AAA and BBB conformers at the B97-D/TZV(2d,2p) level. Both geometries were optimized in $C_{2}$ symmetry. Cartesian coordinates for these conformers are included in a separate file (plain text format). Data for hexa(o-phenylene) had been previously reported. ${ }^{2}$ 
Notably, for hexa(pyrazine-2,3-diyl) the BBB conformer is more stable than the AAA conformer by $2.3 \mathrm{kcal} / \mathrm{mol}$. For the $o$-phenylene, the AAA conformer is more stable by $6.8 \mathrm{kcal} / \mathrm{mol}$. The conformational preference probably results from two factors: First, the bipyrazine bonds should be biased toward transoid conformations so as to minimize repulsion between the nitrogen lone pairs. Second, pyrazine-pyrazine interactions in the $\mathrm{A}_{n-3}$ conformer should be comparatively weak, as the geometry forces the rings to be offset along their $\mathrm{N}-\mathrm{N}$ axes leading to quadrupole-quadrupole repulsion. ${ }^{3}$

Table S2. Energies of hexa(pyrazine-2,3-diyl) at the B97-D/TZV(2d,2p) level. ZPC = zero-point correction; $\mathrm{IF}=$ number of imaginary frequencies.

\begin{tabular}{lrrr}
\hline Conformer & $E\left(E_{h}\right)$ & ZPC $\left(E_{h}\right)$ & IF \\
\hline AAA & -1579.316395 & 0.349534 & 0 \\
BBB & -1579.319990 & 0.349300 & 0 \\
\hline
\end{tabular}

\section{References}

[1] Frisch, M. J.; Trucks, G. W.; Schlegel, H. B.; Scuseria, G. E.; Robb, M. A.; Cheeseman, J. R.; Scalmani, G.; Barone, V.; Mennucci, B.; Petersson, G. A.; Nakatsuji, H.; Caricato, M.; Li, X.; Hratchian, H. P.; Izmaylov, A. F.; Bloino, J.; Zheng, G.; Sonnenberg, J. L.; Hada, M.; Ehara, M.; Toyota, K.; Fukuda, R.; Hasegawa, J.; Ishida, M.; Nakajima, T.; Honda, Y.; Kitao, O.; Nakai, H.; Vreven, T.; Montgomery, J. A., Jr; Peralta, J. E.; Ogliaro, F.; Bearpark, M.; Heyd, J. J.; Brothers, E.; Kudin, K. N.; Staroverov, V. N.; Keith, T.; Kobayashi, R.; Normand, J.; Raghavachari, K.; Rendell, A.; Burant, J. C.; Iyengar, S. S.; Tomasi, J.; Cossi, M.; Rega, N.; Millam, J. M.; Klene, M.; Knox, J. E.; Cross, J. B.; Bakken, V.; Adamo, C.; Jaramillo, J.; Gomperts, R.; Stratmann, R. E.; Yazyev, O.; Austin, A. J.; Cammi, R.; Pomelli, C.; Ochterski, J. W.; Martin, R. L.; Morokuma, K.; Zakrzewski, V. G.; Voth, G. A.; Salvador, P.; Dannenberg, J. J.; Dapprich, S.; Daniels, A. D.; Farkas, O.; Foresman, J. B.; Ortiz, J. V.; Cioslowski, J.; Fox, D. J. Gaussian 09, Rev. B.01; Gaussian, Inc.: Wallingford, CT, 2010.

[2] Mathew, S. M.; Engle, J. T.; Ziegler, C. J.; Hartley, C. S. The role of arene-arene interactions in the folding of ortho-phenylenes. f. Am. Chem. Soc. 2013, 135, 6714-6722.

[3] Mishra, B. K.; Sathyamurthy, N. Stacking interaction in pyrazine dimer. f. Theor. Comput. Chem. 2006, 5, 609619. 